\title{
Grouping of beta-haemolytic streptococci by agglutination
}

\author{
CSF EASMON, SUZANNE EM COX, AND ALISON HOWARD \\ From the Bacteriology Department, Wright-Fleming Institute, St Mary's Hospital Medical School, \\ London W2 IPG, UK
}

SUMMARY Streptococcal grouping sera, diluted and absorbed to remove cross-reactions, were bound to staphylococci and used to group trypsinised beta-haemolytic streptococci by coagglutination. The results compared well with those obtained using the Phadebact streptococcal grouping kit. The same sera bound to staphylococci without prior dilution and absorption could be used to group enzyme extracts of haemolytic streptococci by slide agglutination, the results again comparing favourably with those of the Phadebact kit.

Beta-haemolytic streptococci have traditionally been serogrouped by precipitation reactions using antigen extracts. ${ }^{1-3}$ Agglutination reactions using whole streptococci are unreliable, firstly because the group antigens are not always exposed, and, secondly, because cross-reactions regularly occur. ${ }^{45}$ These problems can be overcome by trypsinisation of the streptococci and by absorption of the grouping sera with cross-reacting streptococcal strains. ${ }^{4}$ Christensen et $a l .5$ have shown that the technique of coagglutination, which is more sensitive than agglutination as it uses a second particle, the antibodycoated staphylococcus in the reaction, can be used to group beta-haemolytic streptococci provided that the antisera are suitable (ie, give no cross-reactions). Pharmacia have produced a kit, Phadebact, for the coagglutination grouping of streptococci groups A, B, C, and G, which is simple, rapid, and reliable and gives results which compare very well with Lancefield grouping. ${ }^{6}$ It is, however, relatively expensive.

In this paper we have examined the practicability, in a busy routine laboratory, of adapting commercial streptococcal grouping sera for use in agglutination tests, paying particular attention to ease of adaptation, reliability, and ease of reading (compared with Phadebact results) and cost. We used two techniques: firstly, a classical coagglutination test with trypsinised streptococci where the antisera were absorbed to remove cross-reactions before use; and, secondly, an agglutination reaction using streptococcal antigen extracted with Strepto-

Received for publication 6 August 1979 myces albus enzyme and lysozyme, ${ }^{7}$ and reagent staphylococci coated with unabsorbed antisera. This method has recently been described by Carlson and McCarthy. ${ }^{8}$

\section{Material and methods}

STREPTOCOCCAL STRAINS

Beta-haemolytic streptococci groups A, B, C, D, and $G$ were obtained from the National Collection of Type Cultures and from clinical sources. The bacteria were stored in liquid nitrogen and grown on Columbia Blood Agar plates (Difco) and in Todd Hewitt broth (BBL).

STREPTOCOCCAL GROUPING REAGENTS Streptococcal grouping sera were bought from Wellcome Reagents and from Difco. Phadebact kits were bought from Pharmacia.

\section{ABSORPTIONS}

The streptococci used for absorbing antisera were grown overnight in Todd Hewitt broth, washed in phosphate buffered saline (PBS), and heat-killed. They were then incubated overnight with $5 \%$ trypsin and washed again. Packed bacterial cells (1 $\mathrm{ml}$ ) were mixed with $2 \mathrm{ml}$ of appropriately diluted antiserum, kept at room temperature for 2 hours, and then at $4^{\circ}$ overnight. The serum was separated and passed through an $0.45 \mu$ millipore filter.

STAPHYLOCOCCAL REAGENT

Staphylococcus aureus Cowan I (NCTC 8530) was grown in Brain Heart Infusion broth (Oxoid) 
overnight at $37^{\circ}$. The staphylococci were harvested, suspended in formalin, washed, heated at $80^{\circ}$ for 5 minutes, washed, and stored as a $10 \%(\mathrm{v} / \mathrm{v})$ suspension in PBS with $0.02 \%$ sodium azide. To this reagent was added either $0.1 \mathrm{ml}$ undiluted streptococcal grouping serum or a larger volume of dilute absorbed serum. After incubation for 1 hour at room temperature, the staphylococci were separated, washed twice in PBS, and resuspended in PBS to the desired concentration.

\section{COAGGLUTINATION TESTS}

The streptococci to be grouped were grown overnight at $37^{\circ}$ in $2 \mathrm{ml}$ Todd Hewitt broth (BBL) supplemented with $0.2 \mathrm{ml}$ of a $5 \%$ solution of trypsin. One drop of the culture was added to one drop of coated staphylococci or Phadebact reagent on a microscope slide, and agglutination reactions were noted. Where bacterial growth in broth was granular, the test was repeated using the broth supernatant.

\section{STREPTOMYCES ALBUS/LYSOZYME}

EXTRACTION AND AGGLUTINATION TESTS

Streptomyces albus enzyme (Difco) was reconstituted with $10 \mathrm{ml}$ of an aqueous solution of lysozyme $5 \mathrm{mg} / \mathrm{ml}$ (Sigma). A few colonies of the organism to be grouped were added to $0.2 \mathrm{ml}$ of the enzyme mixture and incubated at $50^{\circ}$ for 1 hour. After centrifugation, the supernatant was tested against reagent staphylococci coated with unabsorbed grouping sera.

\section{Results}

\section{PREPARATION OF COAGGLUTINATION} REAGENTS

The agglutination titres and cross-reactions of the Wellcome and Difco grouping sera against live trypsinised streptococci are shown in Table 1. The sera were diluted in PBS (groups A and C 1 in 30 , group $B 1$ in 5 , group $G 1$ in 20) absorbed with bacteria of the cross-reacting group and bound to reagent staphylococci, $\mathbf{0 . 2} \mathrm{ml}$ of dilute serum to $1.0 \mathrm{ml}$ of a $10 \%$ staphylococcal suspension. The antibody-coated staphylococci, at a concentration of

Table 1 Agglutination titres and cross-reactions of Wellcome and Difco grouping sera

\begin{tabular}{lrlrll}
\hline Group & \multicolumn{2}{l}{ Wellcome } & \multicolumn{2}{c}{ Difco } \\
\cline { 2 - 3 } \cline { 5 - 5 } \cline { 5 - 5 } & Titre & Cross-reacting group & & Titre & Cross-reacting group \\
\hline A & $>40$ & C & $>40$ & C \\
B & 5 & G & 5 & G \\
C & $>40$ & A & $>40$ & A \\
G & 40 & B & 40 & B \\
\hline
\end{tabular}

$2 \%$, were tested against 16 streptococcal strains of known group (four each of groups A, B, C, and G). All 16 were correctly grouped by both sets of reagents and no cross-reactions were seen. Despite these satisfactory results with stock laboratory strains, the group $B$ and $G$ reagents gave very weak reactions when used against clinical isolates. The group $\mathrm{A}$ and $\mathrm{C}$ reagents gave easily readable results, but these reactions were noticeably weaker than those obtained with the Phadebact kit.

The strength of the coagglutination reagents was, therefore, increased, firstly, by increasing the volume of dilute antiserum used for binding to the staphylococci from $0.2 \mathrm{ml}$ to $1 \mathrm{ml}$ and, secondly, by increasing the working concentration of the antibody-coated staphylococci from $2 \%$ to $5 \%$. With these modifcations the staphylococci coated with both Wellcome and Difco antisera gave strong agglutination reactions within 30 seconds and were used in this form for the rest of the study.

\section{GROUPING OF CLINICAL ISOLATES BY} COAGGLUTINATION

The Phadebact kit and the laboratory-made coagglutination reagents were used to group 121 betahaemolytic streptococci from clinical material. As shown in Table 2, staphylococci coated with Difco

Table 2 Coagglutination grouping of streptococcal isolates

\begin{tabular}{lccc}
\hline Group & Phadebact & Wellcome & Difco \\
\hline A & 36 & 35 & 36 \\
B & 38 & $38+1^{*}$ & $38+1^{*}$ \\
C & 11 & $11+2+$ & $11+2+$ \\
G & 29 & 23 & $29+1^{+}$ \\
A or C & 2 & 1 & 0 \\
B or C & 1 & 0 & 0 \\
B or G & 1 & 3 & 0 \\
Not typable & 3 & $3+3 \S$ & 3 \\
\hline
\end{tabular}

*Phadebact grouping $=\mathrm{B}$ or $\mathrm{C}$

† Phadebact grouping $=\mathrm{A}$ or $\mathrm{C}$

$\dot{\$}$ Phadebact grouping $=\mathrm{B}$ or $\mathrm{G}$

$\S$ Phadebact grouping $=\mathbf{G}$

sera compared well with the Phadebact kit and in fact gave clearcut results on four strains where Phadebact grouping was equivocal. Staphylococci coated with Wellcome sera gave good results with groups $\mathrm{A}, \mathrm{B}$, and $\mathrm{C}$ but were less satisfactory with group G, failing to group six out of 29 strains $(20 \%)$. Three of the six gave equally strong reactions with Wellcome group B serum; the remaining three were too rough to group with the broth culture and failed to group with the culture supernatant. Group $\mathrm{G}$ strains were generally the most difficult to group because of their tendency to produce rough growth 
in broth even in the presence of trypsin. Although we routinely used broth cultures for coagglutination tests, the laboratory-made reagents gave equally good results when tested against streptococci grown on plates and then trypsinised.

The results obtained with all three sets of reagents were checked independently by two other members of the department familiar with the coagglutination technique. No discrepancies were found, and the laboratory-prepared reagents were as easy to use as the Phadebact kit agglutination reactions, usually occurring within 20 seconds.

\section{AGGLUTINATION GROUPING WITH ENZYME} EXTRACTS

Table 3 shows the grouping of clinical streptococcal isolates by Phadebact and by agglutination with enzyme extracts. Only Wellcome sera were used. There was good correlation between the two methods. One strain which grouped as A with the enzyme method grouped as B with Phadebact (group $A$ by Lancefield precipitation), and four strains which gave equivocal results with Phadebact gave clearcut results with enzyme extract agglutination. A few group $G$ extracts gave weak crossreactions with group B serum but these were not strong enough to cause any difficulty in grouping.

Table 3 Grouping of streptococci by Phadebact and by agglutination with enzyme extracts

\begin{tabular}{lcc}
\hline Group & Phadebact & Enzyme extract \\
\hline A & 36 & $36+1 *$ \\
B & 37 & $36+1 \dagger$ \\
C & 11 & $11+2+$ \\
G & 29 & $29+1 \S$ \\
Not typable & 4 & 4 \\
\hline
\end{tabular}

* Phadebact grouping = $\mathrm{B}$

+ Phadebact grouping $=\mathrm{B}$ or $\mathrm{C}$

† Phadebact grouping $=\mathrm{A}$ or $\mathrm{C}$

\$Phadebact grouping $=\mathbf{B}$ or $\mathrm{G}$

Lancefield grouping $=A$

The results with enzyme extracts were reproducible, several different batches being used. Group B extracts gave the most rapid agglutinations, usually in less than 5 seconds, while group A extracts were the slowest, in some cases taking 25 or 30 seconds. This may reflect the greater resistance of group A streptococcal cell walls to enzyme degradation. The Streptomyces albus/lysozyme mixture was stable for at least two weeks at $4^{\circ}$.

AGgLUTINATION REACTIONS OF GROUP D STREPTOCOCCI

Seventeen group D streptococci from clinical material (identified by Lancefield grouping) were tested against the three sets of coagglutination reagents and also using enzyme extract agglutination. Seven of these strains were beta-haemolytic. One group D strain gave a weak coagglutination with all three group $G$ reagents, and both this strain and one other gave a weak positive with group $G$ in the enzyme extract method. Neither strain was haemolytic.

\section{Discussion}

We have shown that it is technically possible to adapt streptococcal grouping sera for use in coagglutination tests, as described by Christensen et al., ${ }^{5}$ by a series of dilutions and absorptions. These are straightforward but, taken with the necessary testing and quality control, are inevitably timeconsuming. Against this must be weighed the large volume of coagglutination reagent that may be prepared from a small quantity of original grouping serum. From $1 \mathrm{ml}$ of group $A$ serum could be produced $30 \mathrm{ml}$ of dilute absorbed serum sufficient to coat $60 \mathrm{ml}$ of staphylococcal reagent at a $5 \%$ concentration. The corresponding figures for group B serum would be $5 \mathrm{ml}$ and $10 \mathrm{ml}$. This means that a large batch of absorbed sera could be prepared, sufficient for six months or even one year, and detailed testing would be required only once during that time. The cost of reagents would also be relatively low. A set of grouping sera (A, B, C, and $G)$ from Wellcome costing just over $£ 30$ would give over $100 \mathrm{ml}$ staphylococcal reagent coated with A or $C$ serum, over $70 \mathrm{ml}$ group $\mathrm{G}$, and $15-20 \mathrm{ml}$ group $B$ reagents. The exact figures would, of course, vary according to the agglutination titres of the batch of sera used, but we have found, by testing various batches in use, that those given in this paper are representative.

The testing of enzyme extracts of streptococci with antibody-coated staphylococci has the advantage of not requiring any absorption of antisera. This confirms the findings of Carlson and McCarthy. ${ }^{8}$ They, too, found some cross-reactions between group $G$ extracts and group B serum but showed that, if troublesome, these could be eliminated by diluting the grouping serum before the staphylococci were coated. This method will be particularly attractive to those laboratories which use enzyme extractions $^{2} 7$ for precipitation tests because of its rapidity and low use of antisera. From $1 \mathrm{ml}$ neat serum can be obtained $20 \mathrm{ml}$ coated staphylococcal reagent if used at a concentration of $5 \%$, or $100 \mathrm{ml}$ if used at $1 \%{ }^{8}$ Enzyme extraction is rapid, enabling a group to be sent out with or even before the antibiotic sensitivity result. 
This work was supported by a grant from the North West Thames Regional Health Authority under their locally organised research scheme.

\section{References}

${ }^{1}$ Lancefield RC. A serological differentiation of human and other groups of hemolytic streptococci. $J$ Exp Med 1933;57:571-95.

2 Maxted WR. Preparation of streptococcal extracts for Lancefield grouping. Lancet 1948 ;2 :255-6.

${ }^{3}$ Rantz LA, Randall E. Use of autoclaved extracts of hemolytic streptococci for serological grouping. Stanford Med Bull 1955;13:290-1.

${ }^{4}$ Rosendal K. Grouping of hemolytic streptococci belonging to groups $\mathrm{A}, \mathrm{C}$, and $\mathrm{G}$ : a comparison between the results obtained by precipitation and by slide-agglutination. Acta Path Microbiol Scand 1956;39:127-36.
${ }^{5}$ Christensen P, Kahlmeter G, Jonsson S, Kronvall G. New method for the serological grouping of streptococci with specific antibodies adsorbed to protein A-containing staphylococci. Infect Immun 1973; 7:881-5.

${ }^{6}$ Finch RG, Phillips I. Serological grouping of streptococci by a slide coagglutination method. J Clin Pathol 1977;30:168-70.

7 Watson BK, Moellering RC, Kunz LJ. Identification of streptococci: use of lysozyme and Streptomyces albus filtrate in the preparation of extracts for Lancefield grouping. J Clin Microbiol 1975;1:274-8.

${ }^{8}$ Carlson JR, McCarthy LR. Modified coagglutination procedure for the serological grouping of streptococci. J Clin Microbiol 1979;9:329-32.

Requests for reprints to: Dr CSF Easmon, Department of Bacteriology, Wright-Fleming Institute, Paddington, London W2 1PG, UK. 